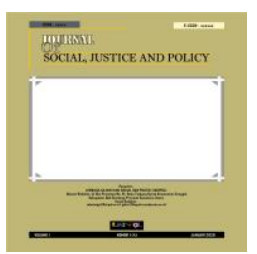

JOURNAL OF SOCIAL, JUSTICE AND POLICY

ISSN (ONLINE): 2809-8080

Volume 1 Number 1 January 2022

\title{
KONDISI SOSIAL EKONOMI PARA PELAKU USAHA MIKRO, KECIL DAN MENENGAH (UMKM) PADA MASA PANDEMI COVID-19 DI KELURAHAN HELVETIA TIMUR
}

\author{
Shania Khairunisa ${ }^{*}$, Agus Suriadi ${ }^{1}$ \\ 1,2Prodi Kesejahteraan Sosial, Fakultas Ilmu Sosial dan Ilmu Politik, Universitas Sumatera Utara \\ * Email: Korespondensi: shaniakhairunisa@gmail.com \\ Email: Agus4@usu.ac.id
}

\begin{abstract}
Based on the results of the research conducted, even though the Covid pandemic condition which caused a decrease in the income of Micro, Small and Medium Enterprises players, they were still able to survive and were still sufficient to meet their needs. The education of the children of UMKM actors is fulfilled up to the informal sector. Adequate living conditions because it is already a permanent home. All MSME actors and their family members are registered in the BPJS program, as well as their employees are registered in the BPJS manpower program. Social interactions with family are harmonious, as well as with fellow business actors. Apart from the ability of MSMEs to maintain their economy during the COVID-19 pandemic, the authors suggest that the government be able to provide assistance that can be distributed evenly so that new and old MSMEs can compete in the future.
\end{abstract}

Keywords: social, economy, UMKM, COVID-19.

\section{Pendahuluan}

Usaha Kecil, Mikro dan Menengah (UMKM) merupakan pelaku usaha yang aktif di berbagai bidang bisnis. Adanya sektor Usaha Kecil, Mikro dan Menengah (UMKM) ini membawa keuntungan bagi perekonomian Indonesia. Usaha mikro dan usaha kecil merupakan usaha informal yang mulai dimunculkan dengan melihat peluang yang ada disekitar. Tentunya usaha tersebut merupakan usaha produktif yang tentunya menghasilkan pendapatan untuk para usahawan yang mendirikan usaha tersebut.

Supriyanto (2006) menyimpulkan dalam penelitiannya teryata UMKM mampu menjadi solusi penanggulangan kemiskinan di Indonesia. Terutama UMKM kuliner di Indonesia yang beranekaragam mulai dari warung, restoran, cafe, bahkan rumahan. Bisnis kuliner sangatlah menjanjikan karena jumlah penduduk Indonesia yang sangat banyak sehingga menjadikan Indonesia menjadi pasar yang sangat besar dengan total pengeluaran konsumen tertingggi di Asia Tenggara.

UMKM ini mempunyai ciri khas yaitu modal yang kecil, resiko yang sedikit tinggi tetapi penerimaan juga tinggi, dan membawa kewirausahaan bagi pemiliknya (Wahyuningsih, 2009).

Pada akhir 2019 hampir seluruh dunia di guncangkan dengan adanya virus COVID-19 (virus corona). Untuk pertama kalinya, virus corona dilaporkan di kota Wuhan,China pada 8 Desember 2019. Virus ini sendiri merupakan ancaman global paling serius di bidang kesehatan yang tidak bisa diabaikan begitu saja karena virus ini menyerang saluran pernapasan hingga menyebabkan kematian. Dan juga virus corona dapat menyebar dengan sangat cepat.

Pemerintah di Indonesia menerapkan kebijakan untuk menyikapi permasalahan ini dengan memberlakukan PSBB (Pembatasan Sosial Berskala Besar),bukan hanya kota Jakarta,tetapi kota-kota besar juga. Kebijakan tersebut dituliskan dalam PP Nomor 21 Tahun 2021(Wardani, 2020). Kebijakan 


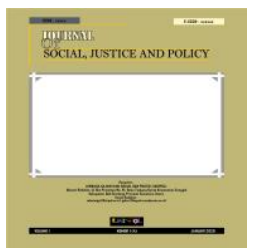

\section{JOURNAL OF SOCIAL, JUSTICE AND POLICY \\ ISSN (ONLINE): 2809-8080}

Volume 1 Number 1 January 2022

ini mengharuskan masyarakat untuk membatasi kegiatan diluar rumah,menggantinya dengan sitem kerja dan belajar secara daring dari rumah. Kebijakan ini diberlakukan untuk memutus mata rantai penyabaran virus COVID-19. Pemerintah juga menerapkan kewajiban untuk melakukan 3M yaitu : memakai masker,mencuci tangan dan juga menjaga jarak

Ada beberapa kelompok rentan terinfeksi virus corona yaitu, menurut Jeanne Marrazzo penderita penyakit kronis seperti penyakit jantung,diabetes,paru-paru rentan mengalami komplikasi karena terinveksi virus corona. Menurut peneliti USA, kelompok penyandang disabilitas mental intelektual keterlambatan mental, orang yang mengalami distrofi otot dan kerusakan otak. Hal ini akibat tidak ada yang dapat menjamin pendekatan dan metode penanganan yang tepat untuk kelompok disabilitas ini. Kelompok rentan berikutnya adalah lansia,semua peneliti dan tokoh otoritas wilayah sepakat bahwa lansia masuk kedalam kelompok berisiko rentan akibat sistem kekebalan tubuhnya melemah seiring dengan pertambahan usia (Siagian, 2020).

Adanya COVID-19 memberikan dampak besar terhadap kehidupan masyarakat, mulai dari kesehatan, ekonomi, sosial, maupun dunia pendidikan. Menurut Direktur Pelaksana IMF, Kristalina Georgieva, dengan adanya wabah virus corona, diperkirakan dalam jangka pendek akan terjadi perlambatan ekonomi global (Budiyanti, 2020). Sejak diterapkannya PSBB banyak pedagang yang tidak diperbolehkan untuk jualan dan mengalami penurunan pendapatan. Tetapi tidak sedikit juga yang tidak dapat bertahan karna mengalami kerugian hingga menutup usahanya.

Seperti mengulang krisis 1997, pada masa pandemi COVID-19 ini dengan diberlakukannya PSBB yang membuat penurunan pendapatan dan menyebabkan kerugian sehingga para pelaku usaha kesulitan untuk membayar kebutuhan usahanya salah satunya menggaji karyawannya. Hal tersebut menyebabkan terjadinya PHK besar-besaran,bukan hanya disektor usaha kecil tetapi di perusahaan besar juga.

Pandemi ini juga dapat memicu konflik sosial dimasyarakat,seperti yang diakibatkan dari adanya PHK, awalnya mereka dapat memenuhi kebutuhannya namun mereka tidak lagi mempunyai pendapatan, kondisi perekonomian menurun, namun kebutuhan hidupnya meningkat. Apalagi jika karyawan yang di PHK tersebut hidup di lingkungan yang berpotensi diskriminasi,ketimpangan sosial politik, yang rentan terhdap konflik antar kelas sosial.

Demi keberlangsungan hidup,banyak orang memulai usaha baru atau memasuki dunia UMKM. Namun itu semua tidaklah mudah, karena adanya pandemi ini yang membuat banyak orang juga membuat usaha atau berusaha memasuki industry UMKM baru yang menyebabkan persaingan semakin tinggi. Walaupun tingkat kebutuhan juga tinggi,tetapi persaingan yang justru meningkat lebih tinggi lagi pastilah memberikan pengaruh pada UMKM lama

Rumusan masalah dalam penelitian ini adalah Bagaimana kehidupan para pelaku Usaha Mikro,Kecil dan Menengah (UMKM) pada masa Pandemi COVID-19 di Kel. Helvetia Timur?. Berdasarkan uraian di atas, maka tujuan penelitian ini adalah untuk mendapatkan gambaran bagaimana kehidupan para pelaku Usaha Mikro, Kecil dan Menengah pada masa pandemi COVID-19 di Kel. Helvetia Timur.

\section{Metode}

Jenis Penelitian ini menggunakan metode penelitian Deskriptif Kualitatif. Dengan penelitian deskriptif ini peneliti ingin memberikan gambaran secara menyeluruh bagaimana kehidupan para pelaku Usaha Kecil Menengah sebelum dan setelah pandemi Covid-19 ini terjadi. Penelitian ini dilakukan di kota Medan, tepatnya di Kel. Helvetia Timur. Dalam pemilihan informan,peneliti 


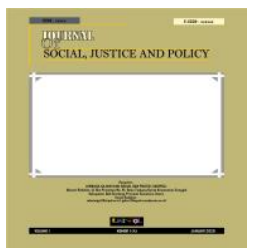

\section{JOURNAL OF SOCIAL, JUSTICE AND POLICY \\ ISSN (ONLINE): 2809-8080}

\section{Volume 1 Number 1 January 2022}

menggunakan teknik bola salju (snowball sampling). Teknik pengumpulan data yang digunakan peneliti untuk mengumpulkan data dalam penelitian ini adalah: 1) studi kepustakaan, yaitu dengan cara mengumpulkan data dan informasi yang menyangkut masalah yang diteliti dengan mempelajari dan menelaah masalah yang diteliti dan referensi kepustakaan, dan 2) studi lapangan, yaitu pengumpulan data yang diperoleh melalui penelitian dengan turun langsung ke lokasi penelitian untuk mencari fakta yang berkaitan dengan subjek penelitian (observasi, wawancara, dokumentasi).

Teknik analisis data yang digunakan adalah metode penelitian kualitatatif. dengan mengkaji data yang dimulai dengan menelaah seluruh data yang tersedia dari beberapa sumber data yang terkumpul, mempelajari data, menelaah, menyusun dalam satu kesatuan yang kemudian dikategorikan pada tahap berikutnya dan memeriksa keabsahan data serta mendefenisikan dengan analisis sesuai dengan kemampuan daya peneliti untuk membuat kesimpulan penelitian.

\section{Pembahasan}

\section{Kondisi Pendidikan}

Pendidikan dapat berkontribusi pada pengembangan sikap wirausaha,kemampuan keterampilan sehingga berdampak pada efikasi diri dan meningkatkan motivasi berwirausaha (Graevenitz, 2010). Dari pengertian diatas dapat diketahui bahwa pendidikan merupakan hal yang penting dalam proses berpikir dan pengambilan keputusan serta membantu kemampuan keterampilan dalam berwirausaha. Pendidikan para pelaku Usaha Mikro, Kecil dan Menengah ada 3 orang yang hanya lulusan SD, satu orang yang lulusan SMA, dan 3 orang yang lulusan Sarjana. Mereka yang berpendidikan rendah berasal dari latar belakang yang kekurangan dalam hal pengehetahuan dan juga materi. Dimasa pandemi COVID-19 ini, walaupun pendapatan mereka menurun, mereka tetap mengutamakan pendidikan anak anaknya. Mereka langsung menyisihkan dari penghasilannya untuk kebutuhan pendidikan anak-anak mereka. Pendidikan tidak menjadi patokan utama dalam menentukan kesuksesan dalam menjalankan usaha tetapi pendidikan sangat membantu dalam menjalankan bisnis. Hal ini terlihat dari para informan yang memiliki pendidikan rendah tidak terlalu mementingkan pembukuan. Mereka tidak mengi ngat atau bahkan tidak menghitung omset yang mereka dapatkan selama setahun atau bahkan dalam sebulan. Sedangkan yang lulusan sarjana lebih teratu tentang pembukuan mereka,mereka bahkan masih menghitung modal yang dikeluarkan hingga saat ini,tidak hanya modal diawal saja. Hal lain dapat dilihat dari cara mengembangkan usaha mereka. Para pelaku usaha yang berpendidikan tinggi cenderung berinovasi untuk mengembangkan usahanya. Dimasa pandemi COVID-19 ini mereka yang berpendidikan tinggi langsung tau harus memberhentikan atau menarik barang barangnya ketika permintaan menurun. Mereka juga mencari jalan lain agar tetap ada pemasukan dengan cara terus update pasaran yang sedang trend sehingga bisa memperluas usaha,tidak hanya berhenti di satu jenis yang mereka jual saja.

\section{Pendapatan}

Menurut Wirutomo (2012) yang mempengaruhi tinggi rendahnya keadaan sosial ekonomi seseorang salah satunya adalah pendapatan. Menurut penelitian yang telah dilakukan, pendapatan perbulan para pelaku UMKM tidak menentu, tetapi pendapatan rata-rata mereka tergolong kedalam golongan pendapatan sangat tinggi karena mendapatkan pendapatan diatas Rp.3.500.000. Dimasa pandemi COVID-19 yang menyebabkan banyak penurunan ini terutama penurunan pendapatan, mereka masih bisa bertahan dan memenuhi kebutuhan mereka. Dengan cara memberhentikan produksi sementara demi menghindari kerugianlah merupakan salah satu cara yang mereka lakukan 


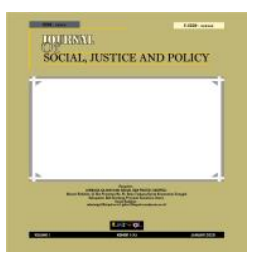

\section{JOURNAL OF SOCIAL, JUSTICE AND POLICY \\ ISSN (ONLINE): 2809-8080}

Volume 1 Number 1 January 2022

untuk bertahan. Hingga sekarang kondisi mereka perlahan- lahan sudah kembali normal. Diwaktuwaktu tertentu seperti lebaran bagi penjual kue kering pesanan justru meningkat. Beberapa acara pernikahan sudah mulai bisa digelar, begitupula dengan bazar. Demikian juga pendapatan mereka selama pandemi COVID-19 ini masih termasuk ke pendapatan golongan sangat tinggi.

\section{Tempat Tinggal}

Rumah berfungsi sebagai tempat untuk melepaskan lelah, tempat bergaul dan membina rasa kekeluargaan diantara anggota keluarga, tempat berlindung dan menyimpan barang berharga, dan rumah juga merupakan status lambang sosial (Mukono, 2000). Menurut hasil wawancara yang dilakukan peneliti, terdapat bahwa para pelaku usaha sudah menempati rumah yang layak huni, yaitu sudah berbentuk rumah permanen secara keseluruhan, sanitasi juga sudah memadai. Hanya ada satu pelaku usaha yang rumahnya masih merupakan rumah sewa. Tempat tinggal mereka juga merupakan tempat mereka melakukan produksi. Dimasa pandemi COVID-19 ini, kebutuhan umum rumah seperti listrik, air masih dapat teratasi. Walaupun ada beberapa informan yang harus menunggak listrik ataupun air, dibulan berikutnya mereka dapat melunasinya. Tidak ada yang harus terpaksa memutus aliran listrik ataupun air dirumahnya. Di masa masa yang sangat membutuhkan internet ini, ada informan yang memilih untuk memasang wifi dirumah demi penghematan dan kebutuhan kecepatan internet itu sendiri. Sehingga tagihan wifi juga termasuk di kebutuhan rumah. Sama seperti air dan listrik, wifi sendiri dapat terbayar lancar dikarenakan sudah menjadi kebutuhan pokok dimasa sekarang ini.

\section{Kesehatan}

Kesehatan keluarga merupakan komponen penting agar dapat berkerja secara produktif sehingga dapat menghasilkan pendapatan dan dapat memenuhi kebutuhan hidupnya. Kesehatan keluarga juga dipengaruhi faktor lain yaitu, pelayanan kesehatan dan perubahan lingkungan (BKKBN, 1995). Seperti wawancara yang dilakukan oleh peneliti kepada para informan ditemukan bahwa semua para informan terdaftar di BPJS kesehatan. Selama pandemi COVID-19 para pelaku UMKM termasuk patuh dalam melaksakan protokol kesehatan yang dianjurkan. Mereka menyediakan tempat untuk mencuci tangan di depan rumahnya. Jika para pelaku UMKM sedang melakukan pertemuan disalah satu rumah produksi,mereka tetap taat memakai masker

\section{Interaksi dengan keluarga}

Terlihat pada semua keluarga para pelaku Usaha Mikro,Kecil dan Menengah, mereka masih menjalin komunikasi dan kontak sosial secara baik, mereka masih rutin mengobrol bersama, melakukan makan bersama dan beribadah bersama. Pada masa sebelum pandemipun mereka senang pergi berlibur bersama minimal setahun sekali bersama keluarganya. Anak yang sudah bekerja yang pisah rumah, juga rutin mengunjungi rumah keluarganya. Dimasa pandemi COVID-19 ini, sulit melakukan perjalanan, bahkan saat ramadhan, seluruh masyarat dilarang untuk mudik, hal ini mengakibatkan anggota keluarga informan yang berbeda kota tidak bisa pulang, sehingga mereka hanya melakukan panggilan telepon ataupun video call demi melepas rindu.

\section{Interaksi dengan Sesama Pelaku UMKM.}

Bukan hanya dengan keluarga,tetapi interaksi sosial terhadap sesama pelaku usaha juga terjalin dengan baik. Mereka sesama pelaku usaha sering berkumpul di rumah usaha informan satu untuk 


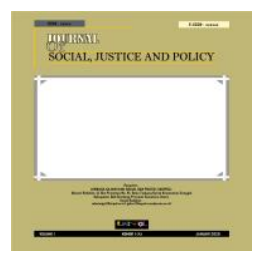

\section{JOURNAL OF SOCIAL, JUSTICE AND POLICY \\ ISSN (ONLINE): 2809-8080}

\section{Volume 1 Number 1 January 2022}

saling berbagi informasi. Apalagi disaat pandemi COVID-19 seperti ini mereka juga masih aktif bertemu. Walaupun terkesan seperti membentuk kerumunan, tetapi mereka paham untuk tidak datang terlalu ramai, dan mematuhi protokol kesehatan. Mereka datang bukan sekedar bercerita,mereka datang untuk saling membantu. Efek dari beberapa karyawan tetap yang dijadikan karyawan borongan,atau beberapa tidak dipanggil sementara, merekalah para sesama pelaku UMKM datang saling membantu dan sambil mencari informasi demi mendapat tambahan pemasukan

\section{Kesimpulan}

Berdasarkan hasil penelitian dan analisis dari data yang dilakukan oleh peneliti tentang kondisi sosial ekonomi para pelaku Usaha Mikro, Kecil dan Menengah (UMKM) pada masa pandemi COVID19 di kel. Helvetia Timur, dapat ditarik kesimpulan bahwa kondisi pelaku UMKM dari awal adanya pandemi mengalami penurunan permintaan, dan penurunan omset secara besar besaran. Hal ini diesebabkan oleh adanya pandemic COVID-19 yang dibuktikan berdasarkan hasil wawancara dengan para informan yang menyebutkan mereka mengalami penurunan sebesar $70 \%$ dari penjualan selama masa pandemi COVID-19, hingga beberapa dari mereka harus memberhentikan sementara produksi mereka demi mengurangi kerugian.

\section{Daftar Pustaka}

Budiyanti, Eka. (2020). Dampak Virus Corona Terhadap Sektor Perdagangan dan Pariwisata Indonesia. Info Singkat, 12(2).

BKKBN. (1995). Kapita Selekta Peningkatan Pelayanan Kontrasepsi. Jakarta.

Gaevenitz, G., Harhoff, D., and Weber, R. (2010). The Effects Of Assessing Strategic Advantages of Family Firms, Family Business Review, 12 (1): 1-22

Mukono HJ. (2000). Prinsip dasar Kesehatan Lingkungan . Surabaya : Airlangga University Press, pp 155-157.

Siagian, Tiadora Hadumaon. (2020). Mencari Kelompok Beresiko Tinggi Terinfeksi Virus Corona Dengan Discourse Network Analysis. Jurnal Kebijakan Kesehatan Indonesia, 9, 98-106.

Supriyanto. (2006). Pemberdayaan Usaha Mikro, Kecil, Dan Menengah(UMKM) Sebagai Salah Satu Upaya Penanggulangan Kemiskinan. Jurnal Ekonomi Pendidikan,3(1),1-16.

Wahyuningsih, Sri. (2009). Peran UKM Dalam Perekonomian Indonesia. Jurnal Ilmu-Ilmu Pertanian, 5(1), 1-14.

Wirutomo, Paulus. (2012). Sistem Sosial Indonesia. Jakarta: Universitas Indonesia 